\title{
Risk Management in Islamic Trade Finance
}

\author{
Ahmet Şuayb Gündoğdu* \\ Islamic Development Bank Group
}

\begin{abstract}
Islamic trade finance, though still not fully developed, has in practice reached the stage in which it calls for a careful review of a wide range of products in export and import financing. The purpose of this paper is to categorize, from a risk management point of view, Islamic trade finance products for asset based\&backed and sub-categories of exports and imports. Each cluster of products would necessitate specific risk measures to be taken for a healthy management of lending and borrowing processes. Asset based Murabaha requires transfer of ownership simultaneously from supplier to financier and from financier to the beneficiary of loan. Hence, risk management practices would be similar to conventional lending. Asset backed Murabaha, on the other hand, necessitates holding ownership of the goods financed and gives rise to certain risk to be managed. This paper highlights the risk areas for asset based\&backed Murabaha and suggests methods to handle the risk associated with processes shaped by the underlying Islamic trade finance contract.
\end{abstract}

Keywords: Islamic trade finance, Murabaha, risk management, Asset Backed Murabaha, export receivable financing, warehouse receipt financing, structured trade finance.

JEL Classifications: G23, G29, G39

\section{İslami Ticaret Finansmanında Risk Yönetimi}

\section{Özet}

İslami Ticaret Finansmanı, her ne kadar henüz tam olgunluğa ulaşmamış olsada, uygulandığı haliyle ithalat ve ihracat finanmanı ürün yelpazesinin detaylı bir gözden geçirilmesine gerek vardır. Bu çalışma risk yönetimi açısından İslami Ticaret Finansmanı ürünlerini Varlığa Dayalı ve Varlık Bazlı ve alt kategori olarakta İhracat\&İthalat olarak sınıflandırmayı önermektedir. Her ürün kümesi için borç verme ve borç alma işlemlerinin sağlıklı yapılabilmesi için spesifik risk yönetimi önlemleri gerektirmektedir. Varlığa Bağli Murabaha'da sahiplik ayni anda tedarikçiden finansöre ve finansörden kredi kullanana geçmektedir. Bunun sonucu olarak risk yönetimi uygulamaları konvasiyonel kredi vermek ile benzeşir. Öte yandan, Varlığa Dayalı Murabaha'da finanse edilen mal sahipliğinin finansör üzerinde tutulmasindan kaynaklanan risklerin yönetilmesi gerekir.

* Ahmet Şuayb Gündoğdu is Country Representative of International Islamic Trade Finance Corporation, Islamic Development Bank Group. Beybi Giz Plaza, Dereboyu Cad., Meydan Sokak, No:1, Kat: 31, Daire:122, Maslak, Sariyer, Istanbul, Turkey. E-mail: ahmetsuayb@hotmail.com 
Bu çalışma Varlığa Bağli ve Varlığa Dayalı Murabaha sözleşmeleri için risk alanlarına dikkat çekerek süreç içinde bu sözleşmeler ile ilgili risklerin yönetilmesi yöntemlerini derinlemesine göstermektedir.

Anahtar kelimeler: İslami ticaret finansmanı, risk yönetimi, varlı̆̆a dayalı Murabaha, ihracat alacak finansmanı, depo sertifikası finansmanı, yapılandırılmış ticaret finansmanı

JEL Sinıflamast: G23, G29, G39

W

ith the increasing demand for Shari'ah compliant financing structures, Islamic trade finance has been soaring and can contribute substantially to the growth of the Islamic finance industry. Today trade has been identified as a major instrument for economic growth and has become involved in the agenda of governments and international organizations: trade enhances economy's access to input for productivity, growth and employment and is strongly supported in Islam. Trade finance is essential for propelling trade, and the early Muslims actively used a Murabaha contract to carry out their trading activities. Even today, according to the World Trade Organization (WTO), 90 percent of overall trade is fulfilled by trade finance. Regardless of its importance, today, there is no accurate data either on trade finance or Islamic trade finance. There are some calculation to derive it from over-all trade levels as a proportion, but they do not supply the needed statistics.

Islamic trade finance, though still not fully developed, has in practice reached the stage in which it calls for a careful review of a wide range of products in export and import financing. This paper aims to contribute to the literature by categorizing, from a risk management point of view, Islamic trade finance products for asset based\&backed and sub-categories of exports\&imports. Each cluster of products would necessitate specific risk measures to be taken for a healthy management of lending and borrowing processes. Asset based Murabaha requires the transfer of ownership simultaneously from the supplier to the financier and from the financier to the beneficiary of the loan. Hence, risk management practices would be similar to conventional lending. Asset backed Murabaha, on the other hand, necessitates holding ownership of the goods financed and gives rise to certain risks to be managed. This paper highlights the risk areas for asset based\&backed Murabaha and gives insight in handling the risk associated with the processes shaped by an underlying Islamic trade finance contract.

Islamic trade finance contracts as categorized by Gündoğdu (2014a) can mainly be in two forms: asset based and asset backed. Asset backed contracts necessitates financier to hold the ownership of the goods financed for certain period of time. The loan seeker in asset backed contract is not borrower but obligor as the contract would stipulate responsibility of loan seeker to purchase the goods financed from the financier under delivery undertaking schedule. On the other hand, asset based contracts operate based on transferring the ownership of goods financed to loan seeker simultaneously from supplier to financier and from financier to loan seeker. The process ends with debt creation; loan seeker becomes borrower at the end. Asset-backed Murabaha is, in 
fact, the authentic form of the Murabaha financing technique, as it is explained in the most of the classical sources of Islamic jurisprudence. It is the asset backed Murabaha which is originally meant by the concept of "Murabaha" in those sources. Asset based Murabaha is a somewhat solution found by Muslims currently. Due to the competition, it has changed into being a conventional loan in many aspects.

As illustrated in Figure 1, asset based and asset backed contracts can also be categorized as export financing and import financing. The different nature of export financing and import financing would necessitate different risk management approaches to address the issues pertaining to the transactions under each.

Figure 1

\section{Islamic Trade Finance Contracts Categorized}

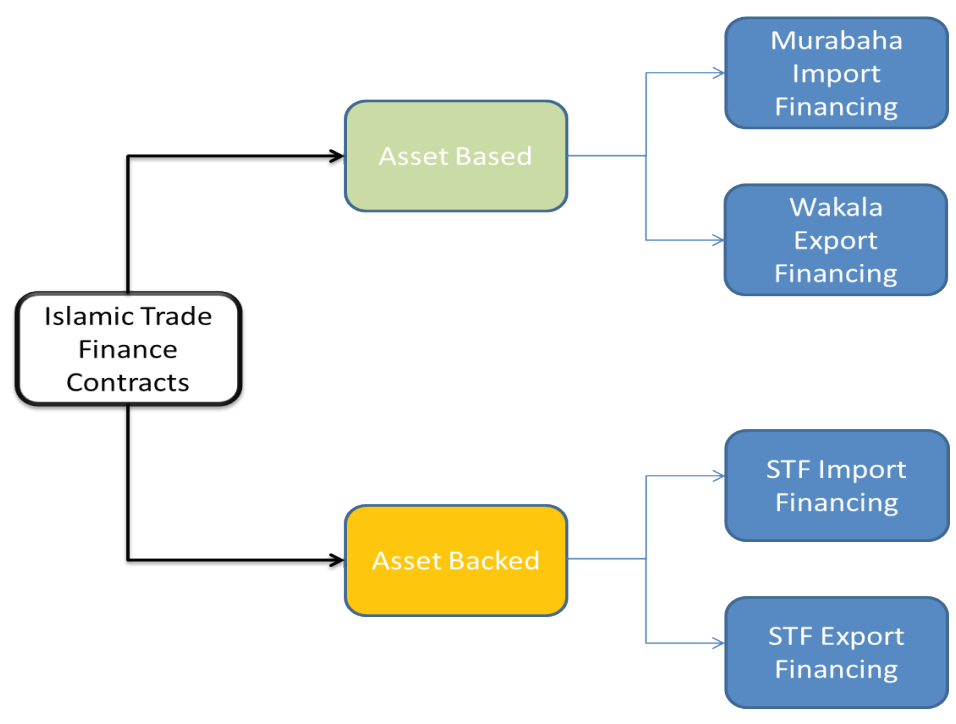

Source: The author

In the case of asset based export financing, the financier needs to assess the credit risk of the off-taker in another country. In the case of asset-backed import financing the main risk is associated with the goods financed and the third parties involved. The cases for each are provided in next sections.

\section{Risk in Asset Based Islamic Trade Finance Contracts}

In a Murabaha import financing contract, the main risk associated with the contract is the borrower's credit risk, since under such structure the financier would not get involved in the goods except for financing them based on a successful representation of the shipping documents. The tools, such as documents collection methods, are well explained in the 
literature. ${ }^{[1]}$ Although there are many contracts types, Murabaha is the one widely used to conduct the transactions. In the case of asset based Murabaha, unlike asset-backed Murabaha in which the title of the goods stays with the financier for a period of time, the transaction is done with an agreement which in essence is more a financing contract. Since there is a simultaneous transfer of ownership, unlike asset backed Murabaha, there is no extra-ordinary legal risk associated. The financier, upon a request for financing for shipping documents that had arrived at their destination, would disburse money to the supplier on behalf of the importer, who is the loan seeker and borrower afterwards. Accordingly, risk management should focus on the credit risk of the importer. The credit risk assessment in Islamic finance, indeed, should not need to be different than conventional financing. The credit risk management for conventional banks has been the subject of many studies. Altman and Saunders (1997) summarized the development in the supposedly well-established area before the 1997 Asian Financial Crisis. Since, then the financial crisis showed that there is a serious flaw with the credit risk management of conventional banks or the products of conventional banks. As argued by Gündoğdu (2014a), fund disbursement to the borrower's account is the major flaw in conventional finance and this flaw nullifies the risk management measures: the financier would not able to control the usage of funds in the core business of the borrower after the disbursement. Loans are expected to be used in the core business of the borrower to generate a future operating cash flow to repay the lenders. If used in speculation, such as real estate ventures, funds would distort the market and create burden of non-performing loans to be borne by the public through state intervention. Credit risk management in its simplest form should cover the assessment of external factors such as the macroeconomic environment of countries, the international prices of FX or commodities, the local regulations, etc. It is the management's ability and the soundness of corporate governance, to address any risk arising from these external factors and their effects on the cash generation capacity of the company to honor its future obligations.

Figure 2

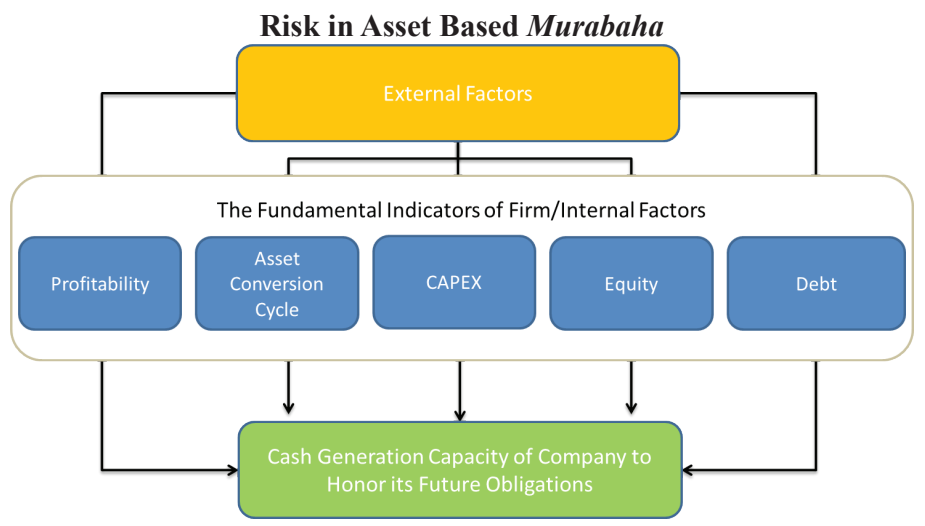

Source: The author

[1] For transaction flow, refer to: Gündoğdu A.Ş. (2009). 2-Step Murabaha as an Alternative Resource Mobilization Tool for Islamic Banks in the Context of International Trade. International Journal of Monetary Economics and Finance. 2(3/4). 
As indicated in Figure 2, risk management for the financier should be focused on an assessment of external factors, the scenarios for possible changes on in these factors, the capacity of the company management to handle external factors and changes, the effects of these factors and the changes in the cash generation capacity of the company through five factors. In asset based Murabaha, the financier assumes profit from the difference between the purchase price and the sale price. The purchase price is the amount of disbursement to the supplier; the sale price is the deferred price to be paid by the loan seeker/borrower. What matters for the financier is the future cash position of the borrower to pay the sale price. Hence, the financial analysis should be based on the effect of the external factors on the future cash generation capacity of the loan seeker because they would affect the profitability, the asset conversion cycle, CAPEX, equity and debt ratios.

As highlighted by Beck and Demirgüç-Kunt (2013), many conventional finance contracts can become Shari'ah compliant with some modification. This conclusion might be more accurate for asset based Murabaha. Nevertheless, there is an important merit with Islamic finance contracts though risk assessment in conventional finance and asset based Islamic finance contracts are similar. Unlike conventional financial institutions, Islamic Financial Institutions would make a disbursement against the transaction, hence, they would have more knowledge on loan usage. In conventional financing, the money would be disbursed to the account of the loan seeker and the loan seeker would have the freedom of usage. In the case of Islamic finance, the money is disbursed to the supplier's account. If this core principle followed by Islamic Financial Institutions, this nature of Islamic finance not only assures the proper usage of the loan in core business but also gives more information to financiers on the business of the borrower. More knowledge would bring about better credit assessment to manage the risk as is shown for asset based Murabaha import financing in Table 1.

Table 1

Risk Management in Islamic Asset Based Import Financing

\begin{tabular}{l|l|l|l}
\hline Risk & Likely Causes & Mitigants & Contingency \\
\hline $\begin{array}{l}\text { Credit Risk of } \\
\text { importer in the } \\
\text { same country }\end{array}$ & $\begin{array}{l}\text { Market conditions to impede generation of } \\
\text { enough cash at the date of maturity }\end{array}$ & Credit Analysis & $\begin{array}{l}\text { Bank Guarantee, } \\
\text { Mortgage }\end{array}$ \\
\hline $\begin{array}{l}\text { Debt } \\
\text { Subordination }\end{array}$ & Other lenders to have higher rank & Pari-Passu Clause & $\begin{array}{l}\text { Bank Guarantee, } \\
\text { Mortgage }\end{array}$ \\
\hline
\end{tabular}

Source: The author

There is extensive know-how on conventional credit analysis and the principles can apply to Islamic lending as well. The Islamic finance industry can benefit from the experience of conventional financing. This would not undermine Shari'ah compliance since it only involves the assessment of the credit worthiness of the loan seeker but not 
the structure of the lending transaction. On the other hand, a rigorous credit analysis would not assure a timely repayment of loans, which is more crucial in Islamic finance than in conventional. Unlike Islamic finance, in the case of conventional finance, financiers would tolerate late payments as they can charge a late payment fee. Islamic asset based Murabaha import financing contracts are not based on interest calculation. On the date of disbursement, the Islamic Financial Institution would inform the loan seeker on the purchase price, the disbursement amount to the supplier, the sale price, and the deferred payment amount to be received from the loan seeker. Once the disbursement is done, Islamic FIs cannot change either the tenor or the sale price. Hence, in the case of a late payment, they would incur losses. Accordingly, Islamic FIs need to have more vigilant risk management approaches for the timely repayment of loans. Asking for mortgages, bank guarantees or Pari-Passu clauses in a Murabaha contract would not only increase the chance of timely repayment but also would mitigate risk of structural subordination. Caminal (2009a), though in the context of sovereign bonds, provided insight on possible controversies on Pari-Passu and on subordination from a legal perspective. Structural subordination of debt happens if at the date of repayment, the financier is not able to be paid since the company had to honor other higher rank obligations such as tax payment due to legal framework, salaries of workers, payment to other lenders who are contractually in a higher rank, or had a mortgage on machinery and property. Besides, some lenders' repayment may fall due before the maturity date of the financier and consume the cash needed for the repayment. If there is a possibility of such subordination, the Islamic FIs can ask for mortgages, bank guarantees and most importantly embed Pari-Passu clauses in the financing agreement. ${ }^{[2]}$ Saying that the issue of mortgage as collateral is another controversial topic for finance industry since it may give rise to adverse selection. Financial Institutions may chose less productive companies with mortgage in expense of more productive companies, if less productive companies accepts higher interest with a similar mortgage. This nature of collateral taking divert funds from more productive companies to less productive ones.

Managing risk associated with asset based import Murabaha contracts is relatively easier to manage as compared to suppler financing Wakala contracts for export financing: under Islamic export financing schemes, Islamic FIs need to assume the risk of the off-taker from another country. The structure of asset based export financing is provided in Figure 3.

[2] Pari-Passu: "A Latin phrase meaning "equal footing" that describes situations where two or more assets, securities, creditors or obligations are equally managed without any display of preference. An example of pari-passu occurs during bankruptcy proceedings: when a verdict is reached, all creditors can be regarded equally, and will be repaid at the same time and at the same fractional amount as all other creditors. Treating all parties the same means they are pari-passu." 
Figure 3

Transaction flow for Asset Based Islamic Export Financing

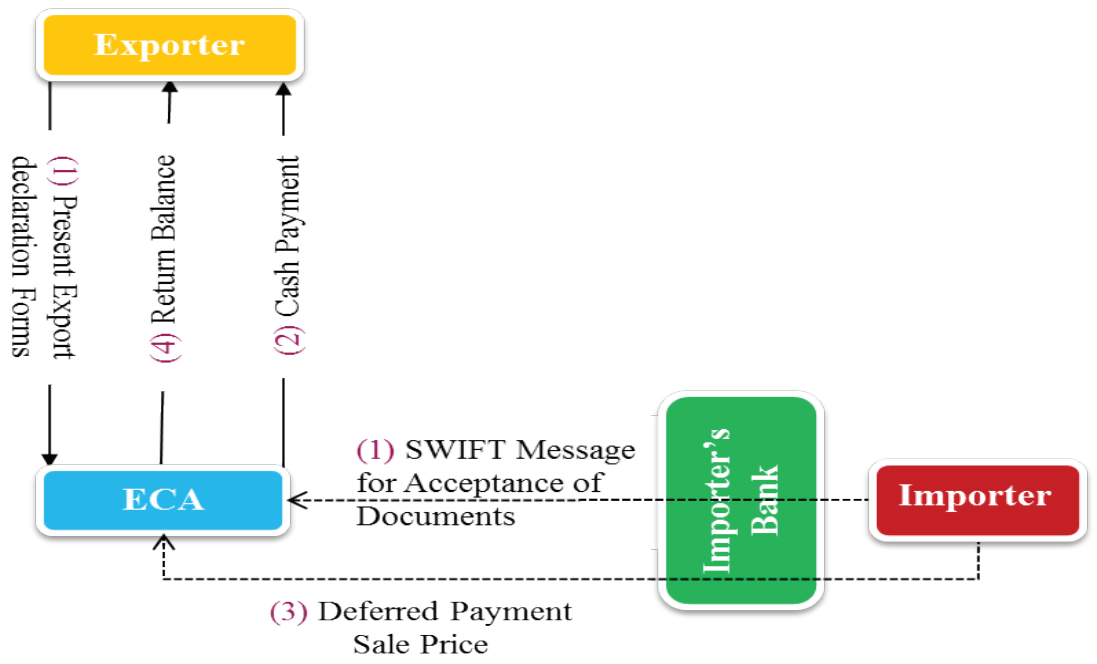

Source: Gundogdu (2016)

The risk management aspects for asset based Murabaha Export, as provided in Table 2 , is not straight forward. Assuming risk of an entity in another country can be a hurdle for risk management: in some countries foreign entities are not allowed to establish legal mortgages, and a bank guarantee would necessitate bank exposure limit setting. Even with Pari-Passu at the rank of debt, local lenders would find ways to subordinate the exporter's debt.

Table 2

Risk Management in IslamicAsset-based Export Financing

\begin{tabular}{l|l|l|l}
\hline Risk & Likely Causes & Mitigants & Contingency \\
\hline $\begin{array}{l}\text { Credit Risk of } \\
\text { Off-taker in } \\
\text { another country }\end{array}$ & $\begin{array}{l}\text { Market conditions to impede generation of } \\
\text { enough cash at the date of maturity }\end{array}$ & Credit Analysis & $\begin{array}{l}\text { Export Receivable } \\
\text { Insurance }\end{array}$ \\
\hline $\begin{array}{l}\text { Debt } \\
\text { Subordination }\end{array}$ & Other lenders to have higher rank & Pari-Passu Clause & $\begin{array}{l}\text { Export Receivable } \\
\text { Insurance }\end{array}$ \\
\hline
\end{tabular}

Source: The author

If it was not possible to obtain a bank guarantee, the only viable method of mitigating debt subordination would be purchasing an export receivable insurance policy 
from a Takaful company. In this regards, the development of Takaful industry is key in product development and future growth of Islamic Finance. The main issue with such policies is that Takaful companies would insure up to $90 \%$ of the export value. Their main motivation behind such practice is to assure that the credit risk assessment of the off-taker is done diligently by financiers. Hence, for proper risk management to operate asset based Islamic finance contracts, Islamic FIs need to develop their credit analysis capacities. In this regard, there should be no hesitation in exploiting the experience of conventional financial institutions.

\section{Risk in Asset-Backed Islamic Trade Finance Contracts}

Asset backed Murabaha contracts necessitate the assumption of the ownership of the goods, usually the commodities, financed. These contracts are signed to operate structured trade finance facilities. Under these structures, the financier would buy easily marketable commodities as requested specifically by the loan seeker; he would then place the commodities in a warehouse, usually bonded, near premises of the loan seeker and then would release the ownership of the commodities upon payment. These are cash and carry types of structures, and collateral are assumed in the form of the commodities financed but are not traditional collaterals such a mortgages. Figure 4 illustrates a case of Black Sea wheat import financing. After the offer and acceptance between the Islamic FI and the beneficiary as per Murabaha agreement:

1. Depending on the price volatility at the date of the financing request, the beneficiary of the facility pays to the Islamic FI a $20-30 \%$ cash deposit of the invoice value.

2. Goods are shipped and documents are presented.

3. Islamic FI pays the Supplier $100 \%$ of the invoice value.

4. Upon receipt of the documents by the Local Agent Bank including Bill of Lading $(\mathrm{B} / \mathrm{L})$, it delivers documents to the Collateral Manager as instructed by the Islamic FI.

5. Commodities are delivered to the Bonded Warehouse under Collateral Management. The CM issues a Warehouse Receipt to the Islamic FI for the commodities under its custody.

6. The beneficiary pays for the value of the commodities it requires to the Islamic FI through the Local Agent Bank.

7. The Islamic FI gives the release instruction to the CM upon receipt of payment.

8. The beneficiary takes delivery of the commodities. 
Figure 4

\section{Transaction Scheme of Asset Backed Murabaha}

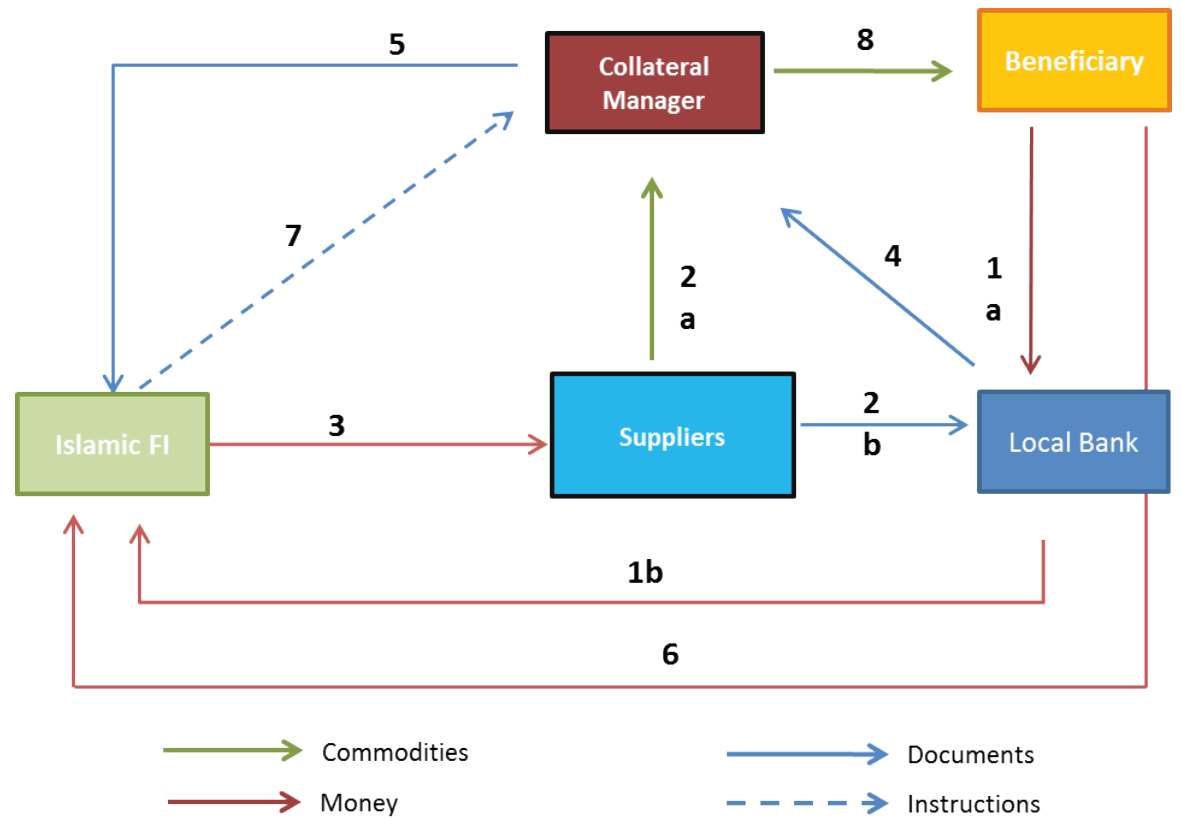

Source: International Islamic Trade Finance Corporation

In case the loan seeker, the beneficiary, is not able to honor its obligation to clear the goods within the pre-specified tenor, the financier has the right to liquidate the commodities by selling them to other off-takers. In an average asset-backed Murabaha trade finance facility, the third parties involved would be: the collateral manager, the insurance company, the facility agent and the off-takers. The facility agent usually is the local bank who manages the day-to-day disbursement-repayment transaction on the ground. The off-takers are a third party who is obliged, by the purchase contract, to purchase goods made ready as per pre-agreed specifications.

An asset backed Murabaha contract may take the form of an import financing facility or an export financing facility against the Assignment of the Sales Contract and Export Receivables. In the case of export financing, the primary purpose of risk management is to use export receivables to mitigate the sovereign risk and FX risks of convertibility or to transfer. Gündoğdu (2014a) in his work for margin calculation presented a case of an import financing scheme under asset backed import financing contract. In the case of asset backed export financing, the main difference from asset backed import financing would be the risk associated with the off-takers in the export markets. Again Gündoğdu (2010) presented a case of cotton export financing for the cotton sector. Since the assetbacked structure has been the subject of other studies, this work directly focused on risk the management elements of asset-backed Murabaha contracts with reference to the literature developed earlier. Unlike asset based Murabaha, by which the contracting 
party is the borrower, in an asset-backed Murabaha loan the seeker is the obligor, not the borrower, and there are third parties who have certain responsibilities to mitigate the risk of the lender. Accordingly, the risk categories, as shown in Figure-5, are different from those of asset based Murabaha. The proposed risk management methods for asset-backed Murabaha are intended to provide a framework for undertaking structured financing solutions for Islamic FIs dealing with international traders. Based on this framework, Islamic FIs would have the ability to design financial structures that are most appropriate for their clients as per the unique needs required due to the transaction or the commodity financed. The proposed framework is not only to provide trade finance solutions, but also to focus on developing and marketing appropriate to the new risk management and credit enhancement solutions that can attract banks and funds in channeling resources/liquidity to asset-backed Murabaha transactions.

Figure 5

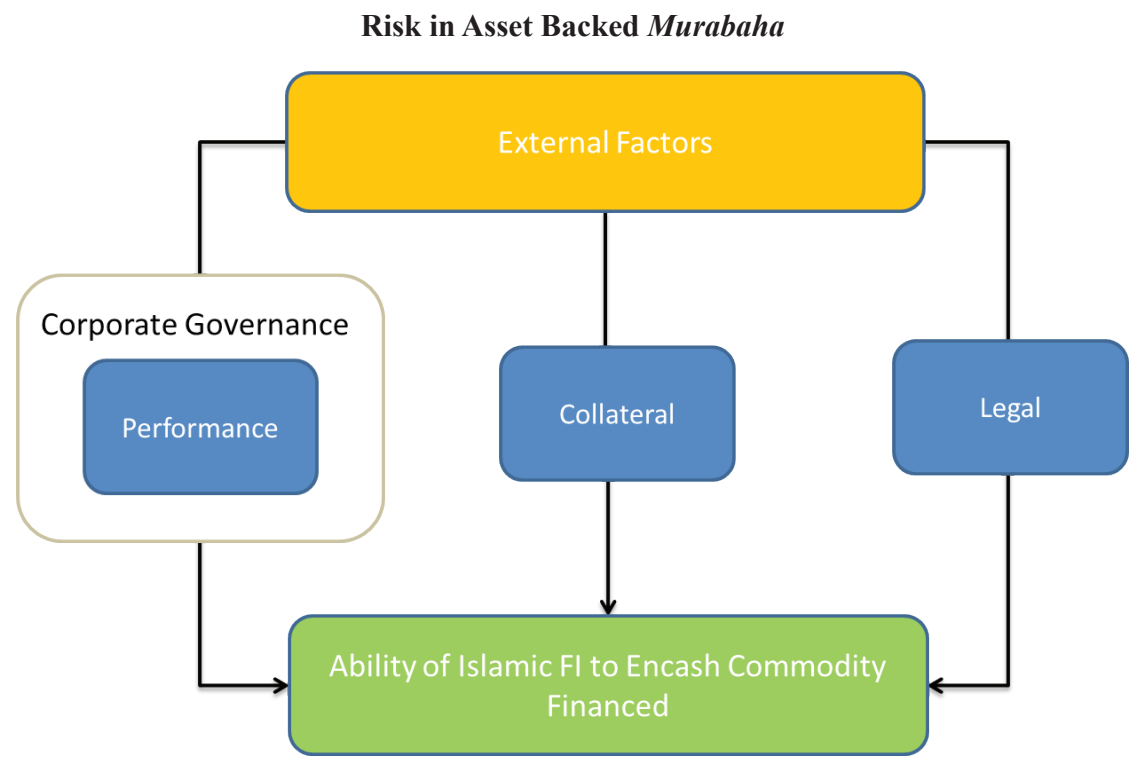

Source: The author

1. Performance Risk: These are risks associated with the main parties involved during the transaction cycle and likely causes and incidents from their intervention if not properly/adequately performed. Risks may be due to lack of competence, mistakes, errors, negligence, fraud etc. These parties are likely to be as follows: the beneficiary, the collateral manager, the off-taker, the transporters, the shipping companies, the insurance underwriters, the freight forwarders, and the collection account bank.

Performance risk for the Beneficiary lies with the attitude and capability to produce and/or sell (in other words, "to deliver") the goods regardless of the circumstances, such as uncertain political situations or conditions of social unrest. It is also a risk associated with the general external environment that influences the beneficiary's ability to 
honor its obligation, particularly in purchasing the commodities as per pre-determined purchase undertaking schedule, such as:

1- The existence of a license, a quota in the domestic market or an import duty in the export market as obstacles to free market valuation. Tax liens (if any) should be checked from time to time.

2- The Risk Management Practices of the beneficiary (FX risk, commodity price risk, etc.).

The financier should evaluate the beneficiary's capacity to handle any risk which may arise out of such areas. In this regard, the corporate governance of the beneficiary should be checked because strong corporate governance standards can increase the internal capabilities to handle such risks. Due diligence should entail a series of onsite visits to the producer, often involving third party experts such as engineers and industry specialists in order to accurately assess the company's ability for corporate governance and assessment of criteria illustrated in Table 3.

Table 3

Eligibility Criteria for the Beneficiary

\begin{tabular}{l|l}
\hline & $\begin{array}{l}\text { The Beneficiary should have a proven operational track record (ability to produce or } \\
\text { process). }\end{array}$ \\
\cline { 2 - 3 } Beneficiary & $\begin{array}{l}\text { The Beneficiary should have a solid business track record (ability to export or sell locally). } \\
\text { business to be financed. }\end{array}$ \\
\cline { 2 - 3 } & $\begin{array}{l}\text { The Beneficiary should not have any pending dispute or investigation for fraud or similar } \\
\text { misdeed. (If recurrent the beneficiary should be rejected.) }\end{array}$ \\
\cline { 2 - 2 } & $\begin{array}{l}\text { Existence of quotas, import/export licenses, tariff barriers, VAT \& other mandatory } \\
\text { regulations. }\end{array}$ \\
\hline
\end{tabular}

Source: The author

The following documents can be obtained from the Beneficiary in pursuit of assuring eligibility criteria:

1- By Laws/Memo/Articles of Association.

2- Board of Directors, Members and position.

3- List of Senior Staff/Management backgrounds or experience and references/ structure diagram.

4- List of shareholders with equity distribution.

5- Last three years Audited Financial Statements (if applicable).

6- The Purchase/Sale Contracts (sample when and where required).

7- The Import/Export License (if any and where applicable). 
8- Understanding/commitment letters of the pre-approved off-takers.

9- Contracts and Export Receivables assignment agreements.

10- Transactions volumes per commodity for the last three years.

11- List of major customers for the last three years.

12- Relevant current financial, technical and operational information evidencing the Beneficiary's ability to operate, process and/or sell successfully.

Given the context in which cross-border physical commodities financing transactions must operate, it is hard to imagine risk management of asset-backed Murabaha in the absence of professional, capable and well-capitalized or well-insured third-party collateral-management service providers. Hence, strong eligibility criteria, particularly the existence of proper professional indemnity insurance, should be adhered to in selection and relationship building with collateral managers as shown in Table 4.

Table 4

\section{Eligibility Criteria/Responsibility for Collateral Manager}

\begin{tabular}{l|l}
\hline \multirow{2}{*}{$\begin{array}{l}\text { Collateral } \\
\text { Manager }\end{array}$} & $\begin{array}{l}\text { CM must be totally independent and of repute with a proven experience in the relevant } \\
\text { fields (the country as well as the type of commodity). }\end{array}$ \\
\cline { 2 - 2 } $\begin{array}{l}\text { CM may be rated by an International rating Agency of an investment grade. } \\
\text { The Collateral Manager must provide an acceptable Professional Indemnity insurance } \\
\text { to cover errors and omissions, fraud and collusions, willful misconduct, etc. from } \\
\text { reputable insurers. }\end{array}$ & $\begin{array}{l}\text { CM agreement to clearly define the role of each party with clear responsibilities of } \\
\text { each contracting party. }\end{array}$ \\
\cline { 2 - 3 } & $\begin{array}{l}\text { CM agreement to ensure full control of the commodity by CM at all times with title of } \\
\text { commodity to the financier. }\end{array}$ \\
\cline { 2 - 2 } & Monitoring reports regularly received from the CM. \\
\hline
\end{tabular}

Source: The author

In addition to the beneficiary and the collateral manager, the performance risk of some third parties should also be of interest. For example, the performance capacity of the freight forwarder and insurance provider/underwriter should be checked. This is can be done by reviewing their membership to international bodies such as the International Federation of Freight Forwarders Associations (FIATA). As for the off-takers, the following criteria can be sought:

1- The off-takers (customers or buyers of the Beneficiary) must be financially sound, economically strong with a good creditworthiness and a proven willingness to honor their contractual commitments (their repayment track record may be consulted). Pre-assigned sales contracts with off-takers should be obtained whenever applicable. Credit assessment might be needed in some cases. 
2- The off-takers should be duly advised of the notice of assignments by the Beneficiary (seller), and the former should unconditionally give their acknowledgement and irrevocably undertake to pay the due receivables of the assigned contract in the assigned collection account. The assignment can be done by facsimile message from the beneficiary to the off-takers by which the beneficiary would ask for acknowledgement of the assignment at the end of the message in the form indicated in Table 5.

Table 5

\section{Assignment of Receivable}

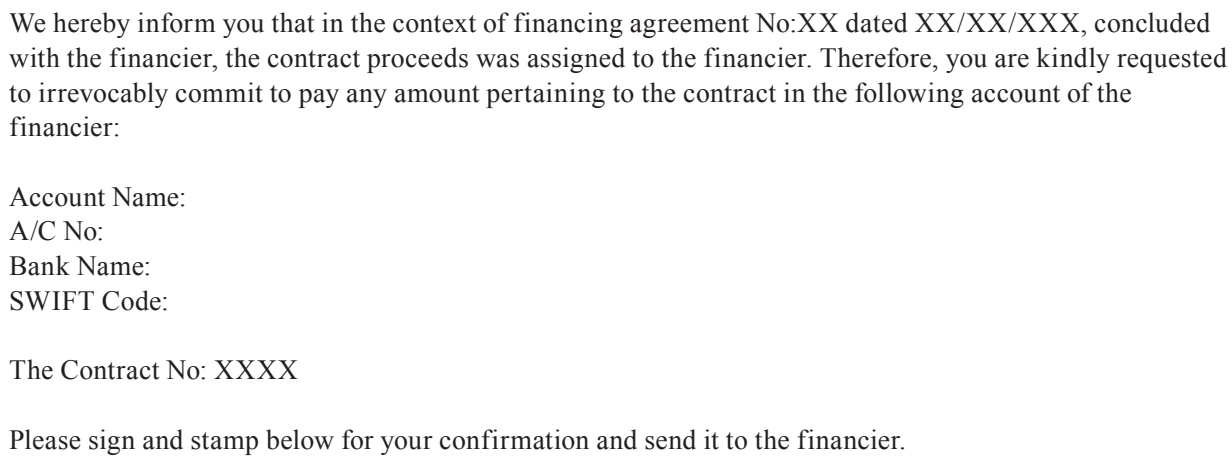

We hereby acknowledge and confirm to pay the proceeds of the above-mentioned contract into the financier's account.

Name:

Signature:

Stamp:

Source: The author

1- Letters of credit issued/confirmed by a bank acceptable to the Islamic FI should be preferred for export financing.

2- Documentary collection can be acceptable for reputable off-takers with a proven track record and an open account may be acceptable against export receivable insurance coverage.

In asset backed Murabaha, there are risks associated with storage, processing, transport, shipment, etc. Risks may arise as a result of moving the commodity either in a raw or finished stage to the final markets for sale and receipt of payment. The process mainly relates to difficulties and risks associated with warehousing and collateral management. Some of these difficulties and the appropriate mitigants are:

1- In case of tolling arrangement, the financing can be implemented in tranches aligned with the inventory build-up schedule, and with the purpose of getting 
the actual usage of the finished goods aligned with the repayment schedules. In this way, the released raw and finished commodity can be properly supervised.

2- Special care should be applied for perishable and semi-perishable commodities, particularly to storage conditions, production and delivery schedules. Hence, appropriate warehousing conditions should be assured for these types of commodities.

3- To apply a reliable monitoring system for both the Collateral Manager (on the Goods' movements) and the financier (on the Collateral Manager's duties) is absolutely necessary.

4- Depending on the country, inappropriate licensing (of Collateral Manager and/ or Warehouse Holder) may generate significant risks, especially when warehousing is a new "technique" in those countries.

5- Finding \& dealing with an Independent and Internationally Reputed Warehouse operator.

6- The collateral must be periodically inspected by independent professionals and marked for market to reflect any quality deterioration and grade.

7- Monitor in the exposure in the event of any environmental degradation caused by the collateral (for example, liability for groundwater contamination by pledged oil products stored in tanks).

These issues necessitate a vigilant selection process required of the collateral manager and the warehousing.

Eligibility criteria for the collateral manager were stipulated above.

As for warehousing, the following eligibility criteria can be sought.

1- The storage facilities or warehouse where the commodity is to be safely kept must be well secured, located in a reasonable place and satisfying all health/safety regulations as mandatory by local laws.

2- It must be an independent warehouse (made to be legally independent) whose legal owner acts only as the custodian of the stored goods. The warehouse operator must not have any ownership interest in the goods kept in custody.

3- A field warehouse may be acceptable provided a qualified independent Collateral Manager has complete and exclusive control on the goods stored inside. The general public must be informed of its control by prominent signs on and around the property showing that the facility is being operated solely by the collateral manager.

4- No third parties including but not limited to 1) the seller of the goods, 2) the financier for the warehouse construction, 3) the collateral manager, 4) the inspection company, and 5) the insurance company, where relevant and applicable - should have any significant lien on the goods stored in the warehouse as long as they are stored inside and the financier has not yet been fully repaid.

5- The warehouse must be appropriately insured with an adequate multi-peril insurance policy against (but not limited to) fire, flooding, typhoons, theft, crumbling, collapse, landslides, etc. 
2. Collateral risks: These are risks associated with the collateral in commodity knowledge, legal aspect and margins. The risk analysis with regard to the collateral can be related to following issues:

1- Property title (ownership, control);

2- Enforceability of the rights (legal title);

3- Misappropriation risk;

4- General liability occurred during normal storage (Third party liability: originating from the collateral, risk of damage to others' asset);

5- Market Value;

6- Ability and experience of collateral manager in subject commodity;

7- Liquidity/disposable (ability to liquidate collateral if needed).

From the legal perspective, the financier should assure the enforceability of warehouse receipt as proof of ownership in the country of the warehouse operator. Hence, the major risk mitigant for such risk is in resorting to legal opinion from an independent legal counsel. As for margins, any decrease in price of the commodity, the collateral, can erode the correlation and consistency between the Financier's exposure and the value of the collateral. Claessens and Duncan (1993) provided extensive case studies on risk management measures to handle such erosion due to the commodity price risk. Nevertheless, conventional finance methods of hedging are usually not Shari'ah compliant. As a practice, a cash deposit is required by Islamic FIs to face this risk. Gündoğdu (2014a) proposed a methodology of calculating the cash deposit margin to address the margin management. The financing value of the collateral must be no greater than the current fair market value of the collateral at the time of disbursement. Commodity collateral should be marked-to-market frequently, and promptly whenever there is any indication of material depreciation in value (for whatever reason) or non-performance by the beneficiary. Also, in these circumstances, the commodity collateral must be re-valued by a professional appraiser and not assessed by references to statistical methods only. These procedures must be fully reflected in the underlying financing agreement. To avoid misappropriation, a third party liability and willful misconduct of the collateral manager, marine insurance and professional indemnity insurance should all be in place. The collateral manager should be selected based on its experience in managing the subject commodity in given country as mentioned above. Besides, to avoid difficulty in case of liquidating the collateral, if the obligor fails to purchase the commodity, there should be criteria for eligible commodities as:

1- The commodity must not be subject to perishability under normal storage conditions over a reasonable time frame.

2- The handling of the commodity is easy and safe and not subject to dangerous manipulation or hazardous implication. 
3- The commodity is readily marketable.

4- The commodity market is liquid and standby off-takers are available.

5- The commodity is fungible.

6- The commodity is at downstream or middle stream level.

7- The commodity's price is set by the market (under supply/demand law) and easily available.

8- The commodity is listed and traded in the relevant futures market (CME group, ICE, LIFFE etc.).

9- In case of import transactions, the quality, quantity, and technical specifications of the commodity are surveyed and analyzed by an independent and internationally recognized inspection company or surveyor at the loading port and if required at unloading (a certificate of analysis, draft surveys) and/or at the storage facilities.

10- The life cycle of the transaction is to be linked to the nature of the commodity (in any case, it should not exceed the life duration of the commodity).

11- The financing amount to the collateral ratio should be more than $100 \%$ so as to give some discount sale margin in liquidation.

12- Appropriate hedging for the Goods and the Proceeds (where appropriate and necessary).

3. Legal risks: Despite all those precautions, some key issues may remain in some cases, and a strong legal team should measure, manage and monitor evolving legal frameworks in subject markets:

1- Financing agreements and other sub-related agreements must be properly drafted to take into account the overriding principle of local laws on security and pledges, applicable in some jurisdictions.

2- Legal opinions on local laws, in all relevant jurisdiction and documentation pertaining to the security interests themselves.

3- Negotiability/Transferability issues: Negotiable Warehouse Receipt Act not formulated (or not yet adequate).

4- The bank's claims as a secured creditor or owner must be senior and be legally perfected as proven by a legal opinion and procedures available for prompt realization of the collateral.

5- Clear markings of the ownership/pledge of the collateral by the Financier at the warehouse/location must be visible in order to deter other creditors.

6- Since the commodity collateral should be marked to market and margins can be called if needed, these features should be fully reflected in the underlying Financing Agreement.

7- Independent and competent (in the field of International Contracts, and of the Commodity Trade Market) Legal Counsel is to be hired. 
8- Negative Pledge clauses on the assets financed such that no sale, transfer or assignment may create any additional security interest under the use of Goods and/or shipments (where required).

9- Legal documentations (at the country's level-FX, title of Property), and at the Beneficiary's level (Articles of Association, By Laws, Certificate of Registration).

Legal enforceability on the physical collateral and/or receivables should be assured. Any security taken over the commodity collateral must be supported by legal opinions confirming enforceability and priority under all applicable laws, and security interests must be properly and timely perfected. The legal mechanism by which the receivables are pledged, assigned or sold must be robust and must ensure that the financier has clear rights over the proceeds. All local steps for the registration of the security must be observed, and the financier must obtain a legal opinion in all relevant jurisdictions. The underlying agreement and available legal remedies must ensure that the financer can liquidate the collateral / proceeds within a reasonable timeframe following default, and have the ability to sell as well as to collect the receivables.

In view of above, the transaction is well "commoditized" and the risk is basically externalized from the Beneficiary to the Commodity and the Collateral Manager, a trusted, independent, reliable third party that provides an indemnity insurance policy stating the financer as loss payee. Since the structure is heavily dependent on the ownership of the goods financed and the third parties such as the collateral manager, the existence of a proper insurance policy is the key to satisfactory risk management. Eligibility criteria for the insurance issue should be stated as:

1- The commodity must be adequately insured at all stages against loss or deterioration, during sailing, when unloaded at arrival port, when stored (transit if any and only if necessary) at berth, while in trucks, train or inland barge towards the warehouse and in the warehouse \& vice versa.

2- Marine and Land insurance policies must be underwritten with a reliable and sound Insurance company re-insured with an international- and investment rated re-insurance company.

3- The financier must be the loss payee of all the insurance policies.

4- Procedures for claim and recovery must be well defined and documented.

In the case of the insurance policy for commodities, loss payee clauses may give rise to loopholes. Since insurance companies, including Takaful, would not honor claims if the premiums for the insurance policy are not paid or, if assured of the policy are insolvent. In this regard, Islamic FIs should be monitoring payment of the insurance premium and the financial health of the assured in asset backed Murabaha deals. The ideal way to tackle insurance risk is to directly be assured of the insurance policy. That is, Islamic Finance can better manage risk associated with insurance by purchasing the insurance policy for each asset backed Murabaha contract. Development of Takaful industry in the area of Marine Cargo and Storage Insurance and Professional Indemnity is vital for growth of asset backed Murabaha. 


\section{Discussion and Conclusion}

This paper attempts to tackle the major issues of how to manage risk and provide a safe and profitable financing environment for both financiers and beneficiaries in asset based and asset backed Murabaha deals. The risk aspect of asset based Murabaha contracts are similar to conventional finance contracts. The asset based Murabaha can be deemed better than conventional facilities as it involves disbursement to the supplier's account and it increases the control of the proper usage of funds. One of the major differences between conventional and Islamic asset based financing is the disbursement account. A Murabaha contract stipulates disbursement to a supplier account, if observed, while in conventional finance, funds are disbursed to a loan seeker's account. Apart from this, and the content of a contract signed between a financial institution and a loan seeker, the risk management practices of conventional financing can more or less be modified to fill the bill for Islamic trade finance. The closer the conventional system is to a bono-fide transaction, the closer it is to Islamic finance. This is particularly the case in Trade Finance and Leasing. Nevertheless, today asset based financing facilities of Islamic banks tend toward converge to conventional ones by disbursing funds to loan seekers' accounts and by charging default interest. Even sticking to very basic features of asset based Murabaha is at risk.

Risk management for asset backed Murabaha necessitates development of relevant techniques to address certain risks for Islamic FIs. The ownership feature under assetbacked Murabaha financing impedes any claim that may arise from the Beneficiary's other creditors and debt subordination. Yet, having ownership also gives rise to certain risks as mentioned. Any finance professional recognizes that there are no risk-free deals; risks always exist in any transaction. Risks are never entirely eliminated; the basic issue is how to tackle the risks. Risks can be assessed and after due identification, they can be either:

1- Transferred (through storage insurance, transport insurance, ECA coverage etc.);

2- Mitigated (hedging, offshore receivables, hard currency off-takers contracts, fixed price contracts, offshore collection, Collateral Manger etc.);

3- Shared (through deposit margin, ECA coverage, other financiers involvement etc.);

4- Managed (supervision, controls, monitoring, robust procedures etc.); or

5- Taken (Force Majeure, where there is no alternative; however it is minimal and very unlikely).

Indeed, Islamic finance principles, which support bono-fide transactions and may refer to Islamic Fiqh Academy rulings, may necessitate financiers taking a risk and inclining towards asset backed Murabaha. The more strictly observed the principles of Islamic finance, the more financiers would indulge themselves into asset backed Murabaha. Unlike asset based Murabaha, the successful implementation of asset backed Murabaha necessitates the involvement of third parties: the collateral manager, the warehouse 
operator, the insurance/Takaful providers, etc. It is vital, and expected, for the Islamic finance industry to develop its relationship with these parties, particularly with Takaful providers in order to properly address the risk associated with the ownership of goods financed under asset backed Murabaha contracts. Hence, Islamic trade finance might be expected to rise on technical capabilities to work with these third parties in order handle and take, if needed, an educated risk in pursuit of healthy lending practices.

\section{References}

Altman, E., Sounders, A. (1998). "Credit Risk Measurement: Developments over the Last 20 Years," Journal of Banking \& Finance, 21: 1721-1742.

Beck, T., Demirgüç-Kunt, A., and Merrouche, O. (2013). "Islamic vs. Conventional Banking: Business Model, Efficiency and Stability," Journal of Banking \& Finance, 37(2): 433-447.

Caminal, R. (2009). "To Rank Pari Passu or not to Rank Pari Passu: That is the Question in Sovereign Bonds after the Latest Episode of the Argentine Saga," Law \& Business Review of the Americas, 15(4): 746-778

Claessens, S., Duncan, R.C. (1993). Managing Commodity Price Risk in Developing Countries. Baltimore: Johns Hopkins University Press.

Financial Accounting Standard No. 2 (FAS 2) (1997). Murabaha to the Purchase Orderer. Manama, Bahrain: AAOIFI.

Gündoğdu, A.Ş. (2009). "2-Step Murabaha as an Alternative Resource Mobilization Tool for Islamic Banks in the Context of International Trade," International Journal of Monetary Economics and Finance, 2(3/4): 286-301.

-----, (2014a). "Two-Step Murabaha in Stock Exchange as an Alternative to Commodity Murabaha for Liquidity Management," International Journal of Financial Services Management, 7(3/4). 268-285.

------, (2014b). "Margin Call in Islamic Finance," International Journal of Economics and Finance, 6(8): 205-213.

------, (2016). "Exploring Novel Islamic Finance Methods in Support of OIC Exports," Journal of Islamic Accounting and Business Research, 7(2): 78-92.

Hasanin, F. (1996). Murabaha Sale in Islamic Banks. Virginia, USA: The International Institute of Islamic Thought.

(IFSB), I.F. (2005). Guiding Principles of Risk Management for Institutions (Other than Insurance Institutions) Offering only Islamic Financial Services. Kuala Lumpur, Malaysia: IFSB.

Khan, T. (2001). Risk Management: An Analysis of Issues in Islamic Financial Industry. Jeddah, Saudi Arabia: Islamic Research and Training Institute.

Yousef, T. M. (2004). "The Murabaha Syndrome in Islamic Finance: Laws, Institutions and Politics," in R. Wilson (ed.), The Politics of Islamic Finance: 63-80. Edinburgh: Edinburgh University Press. 
